\title{
Література:
}

1. Арістотель. Політика / Арістотель; пер. 3 давньогрецької, авт. передм. О. Кислюк. - Київ : Основи, 2000. - 239 с.

2. Еллинек Г. Адам в учении о государстве: Библейское предание и политические теории / Пер. с нем. С. М. Роговина. - М.: Изд-е Н. Н. Клочкова, 1909. - 32 с.

3. Кельман М. С Загальна теорія права : підручник / М. С. Кельман, Г. О. Мурашин. - Київ : Кондор, 2002. -353 с.

4. Слабко С. М. Мораль як ціннісний критерій права / С. М. Слабко // Держава та регіони. Серія : Право. - 2014. - № 3. - С. 8-12.

5. Харт Г. Позитивизм и разграничение права и морали // Правоведение. 2005. № 5. С. 104-136

6. Фуллер Л. Позитивизм и верность праву. Ответ профессору Харту // Правоведение. 2005. № 6. С. 124-159.

DOI https://doi.org/10.30525/978-9934-26-040-7-8

\section{ПРАВОВІ ТА ЕТИЧНІ ДИЛЕМИ В ЛГБТ СПІЛЬНОТІ УКРАЇНИ ТА ПОЛЬЩІ}

\author{
Криган Е. P. \\ студентка І курсу денної форми навчання \\ Науковий керівник: Кобан О. Г. \\ доцент кафедри теорії та історії права та держави \\ Інституту права
}

Київського начіонального університету імені Тараса Шевченка

м. Київ, Україна

Актуальність теми. Iз початком становлення і виокремлення четвертого покоління права, стає зрозуміло, що суспільні ідеї та моралі змінюються, суспільство прогресує, еволюціонує, з'являються нові проблеми, які потребують змін, у тому числі й зміни у правовому регулюванні життедіяльності людей. Останнім часом, усе частіше порушується питання ЛГБТ. Оскільки ця тема в Україні та Польщі до другої половини XX століття залишалася під табу, не дивно, що більшість громадян до сих пір не визначилися із власною, гуманною позицією щодо цієї проблеми. 
Обидві країни займають низькі позиції у Міжнародній асоціації лесбійок, геїв, бісексуалів, трансгендерів та інтерсексуалів. [1] Ще досі фігурують такі фрази як «гей-пропаганда», «західна мода» та «традиційна сім'я». Через відсутність статевого виховання та належної освіченості, більшість громадян обох країн вважають, що легалізація одностатевих шлюбів погіршить демографічну ситуацію, призведе до руйнування традиційної моделі шлюбу, християнських і моральних уявлень про людину та несе загрозу сімейним цінностям. Це $\epsilon$ причиною гомофобії, насилля та свавілля у суспільстві сьогодні.

Найбільшою проблемою невизнання гомосексуальних шлюбів $є$, поперше, відсутність конституційного закріплення проекту про зареєстроване партнерство, який повинен бути законодавчо прийнятим та ефективно впровадженим для визнання та захисту таких пар. По-друге, відсутність та примусова бездітність ЛГБТ із вираженим страхом про своїх нащадків у соціумі в майбутньому. По-третє, нявність колізій у законодавстві, які формально не забороняють одностатеві шлюби, проте також не прописують систему спадкування у таких союзах тощо.

Поставлене питання протягом останніх років активно досліджувалось як науковцями, так і практиками. Існує безліч думок щодо даної проблеми, які різняться між собою. Так, наприклад, Т.С. Кириченко пише: «Оскільки відтворення населення - основна функція сім'ї, то і криза полягає в невиконанні нею "основних" функцій щцдо народження і вихованню дітей» [2]. Справді, більшість науковців вважають найбільшою загрозою одностатевих шлюбів демографічний спад, неможливість народження дітей та руйнування традиційної сім'ї.

В Україні значним каталізатором таких тверджень $\epsilon$ і Православна церква, яка говорить про природу чоловіка і жінки створювати сім'ю та народжувати дітей. За Даниловою I.О.: «...Патріарх Московський $\boldsymbol{i}$ всісї Русі Кирило відзначив, ще до комплексу прав та свобод людини поступово інтегруються ідеї, які суперечать не лише християнським, а й традиційним моральним уявленням про людину" [3]. Нічим не відрізняється і Польща - Католицька церква вчить, що «гомосексуальні акти $є$ внутрішніми розладами душі».

Однак більшість гомосексуальних людей хочуть і можуть мати родину та дітей. Зробити вони це можуть різними шляхами - заводячи фіктивні родини, через стосунки 3 минулого шлюбу, усиновленням, сурогатним материнством, ЕКЗ, через донора яйцеклітини, а також іншими способами, які наразі знаходяться в стадії розробки.

Вважаю за потрібне також згадати розлучення та вплив на дітей. По-перше, в Україні гомосексуалізм не вважається хворобою 
з 1991 року, а в Польщі перший інцідент узагалі трапився у 1932, після чого офіційно затвердився як норма. Гомосексуальність не можна нав'язати, - це те, що притаманне людині від народження, тому орієнтація дитини в майбутньому ніяк не залежатиме від батьків. Так само як і не залежить від орієнтації показник розлучення. Не можна стовідсотково заявляти, що гомосексуальна пара розлучиться скоріше ніж гетеросексуальна, бо всі випадки розриву стосунків $\epsilon$ суб'єктивними та індивідуальними. Поганим батьком може бути як гей, так і чоловік-натурал, але лише із обережності ні влада Польщі, ні влада України не має права позбавляти своїх громадян можливості мати сім’ю. Таким застарілим, егоїстичним, дискримінаційним твердженням не місце у XXI столітті.

В юридичній літературі можна також знайти велику кількість робіт науковців, які досліджують дану проблему з іншого боку.

«Розглядаючи провову базу Украӥни стосовно питань одностатевих илюбів, - як пишуть вони, - в першу чергу необхідно звернутися до Сімейного Кодексу Украӥни. Власне, частина 1 статті 21 цього кодексу визначає, що «Шлюбом є сімейнийй союз жсінки та чоловіка, заресстрований у органі державної ресстрації актів цивільного стану"“ [4]. За чинною Конституцією Польщі: «Шлюб як союз жінки $і$ чоловіка, сім'я, материнство $і$ батьківство знаходяться під охороною і опікою Польської Республіки" [5]. Знову можна прослідкувати схожість обох країн. Фактично, обидві статті ані забороняють одностатеві шлюби, ані дозволяють.

"Статтею 58 Закону Украйни «Про міжнародне приватне право", - пишуть вони, - передбачено, що илюб між громадянами Украӥни, илюб міжс громадянином України та іноземцем, илюб міжс громадянином Украӥни та особою без громадянства, щцо укладений за межсами Украӥни відповідно до права іноземної держави с дійсним в Украӥні за умови додержання щюдо громадянина Украӥни вимог Сімейного кодексу щодо підстав недійсності илюбу" [6]. А оскільки в статті 26 Сімейного кодексу України, в переліку осіб, які не мають права бути одруженими немає осіб однієї статі, то фактично, громадяни України, які є представниками ЛГБТ можуть одружуватись за кордоном.

Закони Польщі не визнають гомосексуальний союз, та вони надають громадянам мати можливість як соціальної допомоги, так i усиновлення. Зокрема за статтею 6.14 «Про соціальну допомогу» від 12 березня 2004 р. зазначається, що якщо один із партнерів має право на отримання соціальних виплат, враховується також і дохід іншого. Право на соціальну допомогу залежить від прибутку на одну особу в 40 
сім'ї. Однак термін «сім'я» вживається і для зазначення осіб, які знаходяться у державному шлюбі, i для де-факто партнерів, які живуть разом. А з 2008 р., якщо один із партнерів зазнав нещасного випадку, або тяжко хворий, інший партнер вважається найближчим родичем при прийнятті ріщень щодо лікування і тд. Визначення «найближчого родича» означає також і особу, яка знаходиться у міцному, тривалому партерстві із пацієнтом.

Краща ситуація в Польщі і щодо наслідування. Поодинокі випадки протистояння геїв із законодавством, наприклад у справі «Козак проти Польщі», надали можливість ЛГБТ особам спадкувати майно свого партнера. У березні 2010 р. ССПЛ постановив, что в одностатевих союзах, у випадку смерті одного з партнерів, з'являється право наслідувати майного. А в рішенні Верховного суду Польщі від 28 листопада 2012 р. встановлюється, що партнер, згідно з статтею 691.1 Громадянського кодексу має право спадкування аренди приміщення свого партнера, у випадку його смерті.

На мою думку, єдине, що заважає обом державам досягнути прогресу у цьому питанні - це застаріла соціальна позиція покоління, яке очолює владу і складає відсоток більшості населення. Україна i Польша - країни, що мають потенціал значно покращити життя своїх громадян. Тут не просто потрібно, а й можливо легалізувати одностатеві шлюби, адже підростаюче покоління ставиться до питань людства 3 глибоким співчуттям і розумінням.

«Польська Республіка, - як визначає стаття 2 чинної Конституції Польщі, -демократична правова держава, що реалізує принципи соціальної справедливості» [5]. За Конституцією України: «Україна є суверенна і незалежна, демократична, соціальна, правова держава" [7]. Отож, оскільки обидві країни $є$ демократичними правовими суб'єктами, зорієнтованими на європейську інтеграцію, в яких діє верховенство права, і в яких всі люди є вільними і рівними у правах, то право на одностатеві шлюби в таких державах повинно бути не виключенням, а поширеною практикою.

\section{Література:}

1. ILGA-Europe - the European Region of the International Lesbian, Gay, Bisexual, Trans and Intersex Association [Електронний ресурс] Режим доступу до ресурсу: https://rainbow-europe.org/\#8665/0/0.

2. Кириченко Т. С. Одностатеві шлюби - міф чи реальність? / Т. С. Кириченко. - 2012. - № 5. - С. 207-210. 
3. Данилова I. О. Визнання одностатевих шлюбів в Україні: бути чи не бути? / I. О. Данилова. // «Young Scientist». - 2017. - № 11. С. 869-871.

4. Миронець О. М. Легалізація одностатевих шлюбів в Україні / О. М. Миронець, Т. С. Ярошенко, А. В. Яценко. // Международный научный журнал «Интернаука». - 2017. - № 16. - С. 56-59.

5. Конституція Польської Республіки (з передмовою Володимира Шаповала) / В.М. Шаповал - К.: Москаленко О.М., 2018. - 82 с.

6. Ткаченко В. Колізійні питання реалізації права на шлюб у міжнародному приватному праві/ Віта Ткаченко. // Підприємництво, господарство і право. - 2020. - № 6. - С. 282-286.

7. Конституція України // Відомості Верховної Ради України (BBP). 1996. № 1. C. 1.

DOI https://doi.org/10.30525/978-9934-26-040-7-9

\title{
ПРАВОВІ ЦІННОСТІ: ЗАГАЛЬНОТЕОРЕТИЧНИЙ ОГЛЯД
}

\author{
Назаренко О. А. \\ кандидат юридичних наук, \\ старший викладач кафедри теорї держави та права \\ Національної академії внутрішніх справ \\ м. Київ, Украӥна
}

Звертаючи увагу на всі політичні та загалом соціальні проблеми $\mathrm{i}$ кризи, які відбуваються у сучасному світі, все дедалі більше необхідними стають існуючі правові цінності, які продовжують нагадувати про те, що незважаючи на ніякі обставини не потрібно нехтувати їх всебічною та загальносоціальною значимістю. Крім того, потрібно завжди пам'ятати і піклуватись про пріоритет збереження загальних правових благ з метою забезпечення не тільки публічних, але й приватних інтересів громадськості. Саме свобода, як невід'ємна правова цінність у житті людини, що надає можливість для її власної самореалізації та самовизначеності повинна залишатись непорушною гарантією суспільного розвитку. Ідеї збереження рівності та справедливості дбають про уникнення безвихідності для вирішення проблем, які регулюються правом та покликані впорядковувати 